\title{
PROFITABILITAS DAN EFISIENSI TEKNIS USAHATANI BAWANG MERAH DI KABUPATEN BANTUL DAN KABUPATEN NGANJUK
}

\author{
Muhammad Fauzan \\ Mahasiswa Pascasarjana Fakultas Pertanian, Universitas Gadjah Mada \\ E-mail: fauzan.ugm@gmail.com
}

\begin{abstract}
The board objective of study is to evaluate the profitability and technical efficiency of shallot farming in Bantul and Nganjuk regency. The specific objectives are to (1) Evaluate the profitability of shallot farmers in the study area and (2) Determine the levefl of technical efficiency of shallot farmers. The primary data used for the study obtained using structured questionnaire administered to 60 selected farmers. Gross margin, net farm income, gross ratio, operation ratio, return on capital invested, and stochastic frontier production function were used to analyze the data. The study showed that (1) shallot farming in Bantul and Nganjuk regency was profitable with net income $R p$ 20.903.711,00/ha and $R p$ 35.294.540,00/ha, (2) the distribution of the technical efficiency indices revealed that the most of the farmers were technically efficient with mean TE Index of 0.802 (Bantul) and 0,929 (Nganjuk), (3) the result of the inefficiency model showed that years of education (Bantul) and age (Nganjuk) significantly increased the farmers technical efficiency
\end{abstract}

Keywords: shallot, profitability, technical efficiency, net farm income

\begin{abstract}
Abstrak: Tujuan utama penelitian ini adalah mengevaluasi profitabilitas dan efisiensi teknis usahatani bawang merah di Kabupaten Bantul dan Kabupaten Nganjuk. Secara spesifik, penelitian ini bertujuan untuk (1) mengetahui profitabilitas usahatani bawang merah di lokasi penelitian dan (2) mengetahui tingkat efisiensi teknis petani bawang merah.Penelitian ini mengggunakan data primer hasil survey pada 60 petani respondendengan menggunakankuisioner yang telah dirancang sesuai dengan tujuan penelitian.Gross margin, net farm income, gross ratio, operation ratio, return on capital invested, danfungsi produksi frontier stokastik digunakan dalam penelitian ini untuk menganalisis data.Hasil penelitian menunjukkan bahwa (1) usahatani bawang merah di Kaupaten Bantul dan Kabupaten Nganjuk menguntungkan untuk dijalankan dengan net income $\mathrm{Rp}$ 20.903.711,00/ha and $\mathrm{Rp} 35.294 .540,00 / \mathrm{ha}$, (2) distribusi tingkat efisiensi teknis menunjukkan bahwa mayoritas petani telah mencapai tingkat yang efisien dengan rata-rata TE Index 0,802 (Bantul) dan 0,929 (Nganjuk), (3) hasil analisis model in-efisiensi menunjukkan bahwa tingkat pendidikan (Bantul) and umur (Nganjuk) berpengaruh signifikan terhadap peningkatan efisiensi teknis petani.
\end{abstract}

Kata kunci: bawang merah, profitabilitas, efisiensi teknis, net farm income

\section{PENDAHULUAN}

Bawang merah merupakan salah satu komoditas sayuran unggulan yang sejak lama telah diusahakan oleh petani secara intensif.Komoditas sayuran ini termasuk ke dalam kelompok rempah tidak bersubstitusi yang berfungsi sebagai bumbu penyedap makanan serta obat tradisonal.Komoditas ini juga merupakan sumber pendapatan dan kesempatan kerja yang memberikan kontribusi cukup tinggi terhadap perkembangan ekonomi wilayah (Balitbang Pertanian, 2005).

Bawang merah dihasilkan hampir di seluruh wilayah Indonesia. Provinsi penghasil utama bawang merah yang ditandai dengan dengan luas areal panen diatas seribu hektar per tahun adalah Sumatera Utara, Sumatera Barat, 
Jawa Barat, Jawa Tengah, Daerah Istimewa Yogyakarta, Jawa Timur, Bali, Nusa Tenggara Barat, dan Sulawesi Selatan. Kesembilan provinsi ini menyumbang 95,5 persen (Jawa memberikan kontribusi sekitar 75\%) dari produksi total bawang merah di Indonesia pada tahun 2013. Konsumsi rata-rata bawang merah per kapita untuk tahun 2011-2012 berkisar antara 2,36 kg/tahun dan 2,74 kg/tahun (Bank Indonesia, 2013). Tabel 1 menunjukkan perkembangan luas panen, produksi, dan produktivitas bawang merah tahun 2007-2013.

Setiap tahun hampir selalu terjadi peningkatan produksi bawang merah, akan tetapi hal tersebut belum mampu mengimbangi peningkatan permintaan bawang merah secara nasional seiring dengan bertambahnya jumlah penduduk dan berkembangnya industri olahan.

Berdasarkan data dari Kementrian Pertanian, pada tahun 2007 misalnya, permintaan bawang merah sebesar 901.102 ton dengan produksi 802.810 ton, tahun 2008 permintaan meningkat menjadi 969.316 dengan produksi 853.615. Pada tahun 2009, permintaan bawang merah di Indonesia mencapai 1.019.735 ton dengan produksi 965.164 ton dan meningkat pada tahun 2010 menjadi 1.116.275 ton dengan produksi 1.048.934 ton.

Tabel 1. Perkembangan Luas Panen, Produksi, dan Produktivitas Bawang Merah di Indonesia Tahun 2007-2013

\begin{tabular}{crrc}
\hline \multirow{2}{*}{ Tahun } & \multicolumn{1}{c}{\begin{tabular}{c} 
Puas \\
\cline { 2 - 4 }
\end{tabular}} & \multicolumn{1}{c}{ Produksi } & Produktivitas \\
\hline 2007 & 93.694 & \multicolumn{1}{c}{ (Ton) } & (Ton/Ha) \\
2008 & 91.339 & 853.610 & 8,57 \\
2009 & 104.009 & 965.164 & 9,35 \\
2010 & 109.634 & 1.048 .934 & 9,57 \\
2011 & 93.667 & 893.124 & 9,54 \\
2012 & 99.519 & 964.221 & 9,69 \\
2013 & 98.937 & 1.010 .773 & 10,22 \\
\hline Rerata & 98.686 & 934.092 & 9,46 \\
\hline Sumber : BPS (2014) & &
\end{tabular}

Umbi bawang merah, khususnya yang memiliki karakteristik kualitas seperti bawang impor (super), yaitu umbi besar (diameter 2,5-3 $\mathrm{cm}$ ), bentuk bulat dan warna merah, mempunyai prospek pasar yang sangat baik di pasar domestik maupun ekspor. Permintaan pasar dalam negeri terus meningkat dari tahun ke tahun.Pada tahun 2015, kebutuhan bawang merah diproyeksikan mencapai 1.195.235 ton.Jika produktivitas bawang merah diproyeksikan mencapai 10,22 ton/ha, maka dibutuhkan sekitar 116.950 ha areal panen. Mengacu pada areal panen tahun 2012, yaitu sebesar 99.519 ha, maka pemenuhan kebutuhan bawang merah tahun 2015 memerlukan perluasan areal panen sekitar 17.432 ha atau sekitar 6.000 ha per tahun.Sasaran produksi sebesar 1.195.235 ton tersebut pada tahun 2015 termasuk untuk benih bawang merah sekitar 102.900 ton (Bank Indonesia, 2013).

Produksi bawang merah di Indonesia masih bersifat musiman seperti hasil pertanian pada umumnya. Hal ini menyebabkan kebutuhan bawang merah masyarakat Indonesia di luar musim panen tidak dapat dipenuhi sehingga untuk memenuhinya perlu dilakukan tindakan impor. Pemerintah melakukan impor bawang merah untuk menjaga ketersediaan bawang merah dalam negeri serta kestabilan harga pasar.Tindakan impor ini menjadikan Indonesia menjadi net importir bawang merah.Setiap tahun Indonesia melakukan kegiatan ekspor dan impor bawang merah, tetapi jumlah ekspor tersebut jauh lebih kecil dibandingkan dengan jumlah impor bawang merah ke Indonesia.

Dalam kurun waktu tiga tahun terakhir (2011-2013) terdapat indikasi kuat bahwa daya saing bawang merah nasional terus menurun dibandingkan bawang merah impor.Kondisi ini diperparah dengan semakin tingginya selisih harga satuan bawang merah ekspor dan impor terkait gejolak nilai rupiah terhadap dollar Amerika Serikat (Bank Indonesia, 2013). Jika kondisi perbedaan harga ini semakin tajam, maka diperkirakan pada tahun-tahun mendatang pun impor bawang merah akan terus menekan produksi dan harga bawang merah nasional. Pada akhirnya, hal ini dapat menurunkan motivasi petani untuk menanam bawang merah dan produksi bawang merah sehingga akan meningkatkan ketergantungan terhadap bawang impor.

Peningkatan produksi yang lambat sementara konsumsi terus meningkat seiring dengan meningkatnya jumlah penduduk dan pendapatan menjadikan ketersediaan bawang merah untuk keperluan rumah tangga dan 
industri makanan seringkali kurang dari kebutuhan dan hal ini mendorong naiknya harga komoditas tersebut.Sebagai tanaman musiman, puncak produksi bawang merah terjadi pada bulan-bulan tertentu, sementara konsumsi bawang merah hampir digunakan setiap hari dan bahkan pada hari-hari besar keagamaan permintaannya cenderung melonjak. Adanya perbedaan pola produksi dan permintaan menyebabkan terjadinya gejolak harga pada waktu tertentu, berupa lonjakan kenaikan harga pada saat permintaan lebih tinggi dari pasokan, atau harga merosot pada saat pasokan lebih tinggi dari permintaan (Bappenas, 2014).

Usaha budidaya bawang merah memiliki prospek dan peluang usaha yang sangat baik di masa yang akan datang. Dari sisi produktivitas, dalam tujuh tahun terakhir (2007-2013) ratarata produktivitas bawang merah nasional hanya sekitar 9,46 ton/ha, jauh dibawah potensi produksi yang berada diatas 20 ton/ha. Beberapa permasalahan rendahnya produktivitas tersebut antara lain : (a) ketersediaan benih bermutu, (b) prasarana dan sarana produksi terbatas, (c) belum diterapkannya SOP (Standard Operating Procedurs) spesifik lokasi secara benar sehingga belum dapat diatasinya permasalahan yang ada.

Untuk mencapai produktivitas yang maksimal, sistem budidaya bawang merah harus dilakukan secara intensif sehingga perlu ketrampilan dan keuletan ekstra dari setiap individu petani.Mengkaji persoalan tentang produktivitas sebenarnya adalah mengkaji masalah efisiensi usahatani. Hal ini dikarenakan ukuran produktivitas pada hakikatnya mempengaruhi tingkat efisiensi teknis budidaya yang dilakukan oleh petani yang menunjukkan pada seberapa besar output maksimum yang dapat dihasilkan dari tiap input yang tersedia. Tingkat efisiensi akan sangat dipengaruhi oleh kapabilitas manajerial petani dalam aplikasi teknologi budidaya dan pasca panen, serta kemampuan petani dalam mengakumulasikan dan mengolah informasi yang relevan dengan usaha budidayanya sehingga pengambilan keputusan dapat dilakukan dengan tepat.

Isu inefisiensi pada dasarnya timbul dari asumsi bahwa petani dan usahatani berperilaku memaksimalkan keuntungan.In-efisiensi dapat diintepretasikan sebagai suatu titik atau tahapan dimana tujuan dari perilaku ekonomi belum secara penuh dimaksimalkan.Kemungkinan seorang pelaku tidak dapat mencapai tujuan maksimalnya adalah sesuatu yang umum. Dengan kata lain, in-efisiensi sebenarnya merupakan bagian yang tidak terlepaskan dari kehidupan (Adiyoga, 1999).

Dalam mengelola usahataninya, petani mungkin saja melakukan penyimpanganpenyimpangan yang menimbulkan konsekuensi-konsekuensi. Dinamika sektor pertanian yang ditandai oleh adanya perubahan lingkungan teknis dan ekonomis secara terusmenerus akan menyulitkan petani dalam menyesuaikan keputusan-keputusan alokatifnya agar tetap respon terhadap perubahan lingkungan produksi serta tetap menjaga efisiensi alokasi penggunaan sumberdayanya. Pada kondisi seperti ini petani sebenarnya secara terus-menerus berada pada keadaan disekuilibrium.Dinamika perubahan lingkungan strategis yang dihadapi petani juga mensyaratkan kriteria efisiensi yang lebih diarahkan pada keragaan sistem (termasuk di dalamnya petani dan sistem penunjang usahatani), bukan semata-mata difokuskan secara sempit kepada rasionalitas petani (Adiyoga, 1999).

Besarnya peluang untuk menjangkau pasar nasional maupun pasar internasional menjadikan bawang merah sebagai salah satu komoditi prioritas dalam pengembangan sayuran di Indonesia, yang cukup strategis dan ekonomis dipandang dari segi keuntungan (profit) usahatani. Semakin tinggi keuntungan usahatani yang dicapai oleh petani akan menunjukkan keberhasilan petani dalam menjalankan usahataninya secara ekonomi. Untuk itu, pengembangan usahatani bawang merah di Indonesia harus diarahkan untuk mewujudkan agribisnis dan agroindustri yang berdaya saing, berkelanjutan, dan mampu meningkatkan kesejahteraan petani.

Profitabilitas usahatani bawang merah menjadi sangat penting untuk diketahui sebagai bahan pertimbangan dalam mengambil keputusan tentang penggunaan teknologi dengan tujuan untuk meningkatkan produksi sekaligus meningkatkan keuntungan petani.Setiap petani bawang merah tentu mengharapkan produksi yang tinggi dan sekaligus keuntungan yang memadai.Dalam 
menghadapi kondisi lingkungan yang serba tidak menentu, seorang petani harus mampu mengalokasikan faktor-faktor produksi yang digunakan sedemikian rupa sehingga usahataninya dapat mencapai tingkat yang efisien dan memperoleh keuntungan yang cukup untuk menghidupi keluarganya dan sekaligus mengembangkan usahataninya.

Berdasarkan uraian diatas maka pertanyaan yang akan dijawab dalam penelitian ini adalah: 1) Berapakah profitabilitas usahatani bawang merah? 2) Apakah usahatani bawang merah sudah efisien?

\section{METODE PENELITIAN}

Penentuan lokasi penelitian dilakukan secara purposive di dua kabupaten, yaitu Kabupaten Bantul, Daerah Istimewa Yogyakarta dan Kabupaten Nganjuk, Provinsi Jawa Timur.Responden di Kabupaten Bantul berasal dari tiga kecamatan yang memiliki rerata produktivitas tertinggi yaitu Kecamatan Sanden, Kretek, dan Srandakan, dimana kesemuanya merupakan petani bawang merah di lahan sawah.Responden di Kabupaten Nganjuk hanya diambil dari petani di Kecamatan Rejoso, yang merupakan salah satu kecamatan dengan produktivitas bawang merah yang tertinggi.

Penentuan sampel petani di setiap kabupaten dilakukan secara purposive (sengaja) dengan kriteria petani yang menanam padi atau palawija terlebih dahulu sebelum menanam bawang merah.Hal dimaksudkan agar dapat diketahui biaya pengolahan tanah yang sebenarnya.Pada masing-masing kabupaten dipilih 30 orang petani.

Profitabilitas usahatani bawang merah dalam penelitian ini dianalisis dengan menghitung Gross Margin (GM), Gross Ratio (GR), Operating Ratio (OR), Return of Capital Investment (ROI), dan Net Farm Income (NFI), yang masing-masing dijelaskan sebagai berikut:

a. Gross Margin (GM)

Analisis Gross Margin adalah salah satu metode untuk menghitung profitabilitas usahatani skala kecil (Olukosi et. al., 2006 dalam Ojo at. al., 2009). Perhitungan Gross Margin dapat diformulasikan sebagai berikut :

$$
\begin{aligned}
\mathrm{GM} & =\mathrm{GFI}-\mathrm{TVC} \\
\operatorname{dimana}: & \\
\mathrm{GM} & =\text { Gross Margin } \\
\mathrm{GFI} & =\text { Gross Farm Income } \\
\mathrm{TVC} & =\text { Total Variable Cost }
\end{aligned}
$$

b. Gross Ratio (GR)

Gross Ratio adalah rasio profitabilitas yang digunakan untuk mengukur keberhasilan usahatani dalam menghasilkan keuntungan secara keseluruhan. Perhitungan Gross Ratio dapat diformulasikan sebagai berikut :

$$
\mathrm{GR}=\frac{T F E}{G F I}
$$

dimana :

$$
\begin{aligned}
\mathrm{GR}= & \text { Gross Ratio } \\
\mathrm{TFE}= & \text { Total Farm Expenses } \\
\mathrm{GI}= & \text { Gross Farm Income } \\
& \text { (Pendapatan Kotor Usahatani) }
\end{aligned}
$$

Semakin rendah rasio berarti semakin tinggi tingkat pengembalian per rupiah.

c. Operating Ratio (OR)

Operating Ratio adalah rasio profitabilitas yang terkait langsung (directly related) dengan tingkat penggunaan input variabel. Semakin rendah rasio berarti semakin tinggi profitabilitas dari bisnis pertanian. Perhitungan Operating Ratio dapat diformulasikan sebagai berikut :

$$
\mathrm{OR}=\frac{T O C}{G F I}
$$

dimana :

$$
\begin{array}{ll}
\mathrm{OR} & =\text { Operating Ratio } \\
\mathrm{TOC} & =\text { Total Operating Cost } \\
\mathrm{GI} & =\text { Gross Farm Income }
\end{array}
$$

d. Return on Invested Capital (ROIC)

Return on Invested Capital digunakan untuk mengukur tingkat pengembalian atas modal yang telah diinvestasikan. Return on Invested Capital juga didefinisikan sebagai Gross Marjin yang dibagi dengan Total Variable Cost. Hal ini dapat diformasikan sebagai berikut :

$$
\mathrm{ROIC}=\frac{G M}{T V C}
$$

dimana :

$$
\begin{array}{ll}
\mathrm{ROIC} & =\text { Return on Invested Capital } \\
\mathrm{GM} & =\text { Gross Marjin } \\
\mathrm{TVC} & =\text { Total Variable Cost }
\end{array}
$$


e. Net Farm Income (NFI)

Net Farm Income adalah pendapatan bersih atau keuntungan dari usahatani.Net Farm Income menunjukkan kemampuan usahatani dalam menghasilkan laba (keuntungan).Net Farm Income dapat diformasikan sebagai berikut :

$$
\mathrm{NFI}=\mathrm{GM}-\mathrm{TFC}
$$

dimana :

$$
\begin{aligned}
\mathrm{NFI} & =\text { Net Farm Income } \\
\mathrm{GM} & =\text { Gross Marjin } \\
\mathrm{TFC} & =\text { Total Fixed Cost }
\end{aligned}
$$

Kemudian tingkat efisiensi teknis usahatani bawang merah dianalisis menggunakan fungsi produksi frontier stokastik tipe Cobb-Douglas, dengan spesifikasi sebagai berikut :

$\ln Y=\beta_{0}+\beta_{1} \ln X_{1}+\beta_{2} \ln X_{2}+\beta_{3} \ln X_{3}+\beta_{4} \ln$ $X_{4}+\beta_{5} \ln X_{5}+\beta_{6} \ln X_{6}+\beta_{7} \ln X_{7}+\beta_{8} \ln$ $X_{8}+\beta_{9} \ln X_{9}+\beta_{10} \ln X_{10}+\beta_{11} \ln X_{11}+$ $\beta_{12} \ln \mathrm{X}_{12}+\left(\mathrm{v}_{\mathrm{i}}-\mathrm{u}_{\mathrm{i}}\right)$

Keterangan :
$\mathrm{Y}$ : Produksi bawang merah $(\mathrm{kg})$
$\mathrm{X}_{1}$ : Luas Lahan $\left(\mathrm{m}^{2}\right)$
$\mathrm{X}_{2}:$ Benih $(\mathrm{kg})$
$\mathrm{X}_{3}:$ Pupuk Urea $(\mathrm{kg})$
$\mathrm{X}_{4}$ : Pupuk ZA $(\mathrm{kg})$
$\mathrm{X}_{5}$ : Pupuk SP-36 $(\mathrm{kg})$
$\mathrm{X}_{6}$ : Pupuk $\mathrm{KCl}(\mathrm{kg})$
$\mathrm{X}_{7}:$ Pupuk NPK-Phonska $(\mathrm{kg})$
$\mathrm{X}_{8}$ : Pupuk Petroganik (kg)
$\mathrm{X}_{9}:$ Hebisida $(\mathrm{ml})$
$\mathrm{X}_{10}$ : Fungisida (gr)
$\mathrm{X}_{11}$ : Insektisida $(\mathrm{ml})$
$\mathrm{X}_{12}$ : Tenaga Kerja (HKO)
$\beta_{0}:$ Intersep
$\beta_{\mathrm{i}} \quad$ : Koefisien Regresi

$\mathrm{v}_{\mathrm{i}}$ : Kesalahan yang dilakukan karena pengambilan secara acak (kesalahan yang disebabkan oleh hal yang tidak dikuasai oleh petani).

$\mathrm{u}_{\mathrm{i}}$ : Efek dari inefisiensi teknis yang muncul (kesalahan yang dikuasai oleh petani).

Untuk menentukan nilai efek inefisiensi teknis $\left(\mathrm{u}_{\mathrm{i}}\right)$ pada penelitian ini digunakan persamaan : $\mathrm{u}_{\mathrm{i}}=\delta_{0}+\delta_{1} \mathrm{Z}_{1}+\delta_{2} \mathrm{Z}_{2}+\delta_{3} \mathrm{Z}_{3}+\mathrm{w} \ldots$

dimana faktor-faktor yang mempengaruhi inefisiensi teknis meliputi :

$$
\begin{array}{ll}
\mathrm{Z}_{1} & : \text { Umur Petani (tahun) } \\
\mathrm{Z}_{2} & : \text { Pendidikan (tahun) } \\
\mathrm{Z}_{3} & : \text { Pengalaman (tahun) }
\end{array}
$$

Pendugaan parameter dari persamaan (1) dan (2) dengan metode Maximum Likelihood Estimation (MLE) dilakukan secara simultan yaitu menggunakan program software FRONTIER 4.1 Coelli (1996). Dengan menggunakan program ini maka akan didapatkan efisiensi teknis dari usahatani bawang merah, dengan perhitungan :

$$
T E_{i}=\frac{Y}{Y^{*}}=\frac{E\left(Y_{i} \mid U_{i}, X_{i}\right)}{E\left(Y_{i} \mid U_{i}=0, X_{i}\right)}=
$$

Keterangan :

$\mathrm{TE}_{\mathrm{i}} \quad$ : Efisiensi teknis petani ke $\mathrm{i}$

Y : Produksi Aktual

$\mathrm{Y}^{*} \quad$ : Produksi Potensial (Diperoleh dari fungsi produksi frontier stokastik)

Dimana $0 \leq \mathrm{TE}_{\mathrm{i}} \geq 1$

Jika nilai TE semakin mendekati 1 (satu) maka usahatani bawang merah dapat dikatakan semakin efisien secara teknis dan jika semakin mendekati 0 (nol) maka usahatani bawang merah dapat dikatakan in-efisien secara teknis.

Suatu metode produksi dapat dikatakan lebih efisien dari metode lainnya jika metode tersebut menghasilkan output yang lebih besar pada tingkat korbanan yang sama. Suatu metode produksi yang menggunakan korbanan yang paling kecil, juga dikatakan lebih efisien dari metode produksi lainnya jika menghasilkan output yang sama besarnya. Mubyarto (1982) menyatakan bahwa efisiensi dalam usahatani merupakan salah satu indikator keberhasilan proses produksi.

\section{HASIL DAN PEMBAHASAN}

\section{Pola Tanam}

Pola tanam adalah suatu urutan tanam pada sebidang lahan dalam kurun waktu satu tahun.Pola tanam biasanya bersifat spesifik wilayah sesuai dengan kondisi geografis, iklim, dan sosial budaya.Pola tanam diatur dengan 
tujuan untuk memanfaatkan sumberdaya secara optimal dan untuk menghindari risiko kegagalan. Pola tanam yang dominan dijumpai di wilayah sentra produksi bawang merah di Kabupaten Bantul dan Kabupaten Nganjuk adalah sebagai berikut :

Kabupaten Bantul

(Kecamatan Sanden, Kretek, dan Srandakan)

Padi (MH, Nov-Feb) - Bawang Merah + Cabai Merah (MK I, Maret-Juni) - Bawang Merah + Cabai Merah (MK II, Juli - Okt)

Kabupaten Nganjuk

(Kecamatan Rejoso)

Padi (Nov-Feb) - Kedelai (Maret-Mei) Bawang Merah (Juni-Agustus) - Bawang Merah (Sept-Okt)

Terdapat perbedaan yang cukup jelas antara pola tanam petani bawang merah di Kabupaten Bantul dengan petani bawang merah di Kabupaten Nganjuk.Di lokasi yang disebutkan pertama, bawang merah ditanam secara tumpang sari dengan tanaman cabai merah, baik di Musim Kemarau I (MK I) maupun di Musim Kemarau II (MK II).Cabai merah biasanya ditanam 25 hari setelah bawang merah ditanam. Tanaman bawang merah sendiri akan dipanen pada umur 50-60 hari, sementara tanaman cabai merah akan terus dipertahankan hingga waktu tanam bawang merah berikutnya tiba.

Sementara itu, petani bawang merah di Kabupaten Nganjuk, khususnya di Kecamatan Rejoso, memiliki pola tanam yang berbeda.Bawang merah ditanam dua kali dalam setahun secara monokultur biasanya pada bulan Juni dan September.Satu hal yang cukup menarik di Kabupaten Nganjuk adalah pemilihan tanaman kedelai untuk ditanam setelah padi dan sebelum bawang merah.Secara teoritis, tanaman kedelai adalah salah satu jenis tanaman leguminosa yang dapat bersimbiosis mutualisme dengan mikroorganisme tanah seperti Rhizobium. Simbiosis ini pada akhirnya akan dapat meningkatkan kadar Nitrogen di dalam tanah, yang nantinya akan bermanfaat bagi tanaman bawang merah yang ditanam setelahnya.

\section{Penggunaan Sarana Produksi (Pupuk, Pestisida, dan Tenaga Kerja)}

Pupuk adalah bahan yang mengandung satu atau lebih unsur hara yang ditambahkan kepada tanaman baik secara langsung maupun tidak langsung.Rata-rata penggunaan pupuk untuk usahatani bawang merah dapat dilihat pada Tabel 2.

Tabel 2. Rerata Penggunaan Pupuk untuk Usahatani Bawang Merah

\begin{tabular}{|c|c|c|c|c|}
\hline \multirow{2}{*}{$\begin{array}{c}\text { Jenis Pupuk } \\
(\mathrm{kg} / \mathrm{ha})\end{array}$} & \multicolumn{2}{|c|}{ Kab. Bantul } & \multicolumn{2}{|c|}{ Kab. Nganjuk } \\
\hline & $\mathrm{N}$ & Rerata & $\mathrm{N}$ & Rerata \\
\hline Urea & 18 & 153,93 & 29 & 331,86 \\
\hline ZA & 14 & 282,69 & 28 & 323,83 \\
\hline SP-36 & 20 & 380,07 & 19 & 403,88 \\
\hline $\mathrm{KCl}$ & 21 & 188,67 & 13 & 129,19 \\
\hline $\begin{array}{l}\text { NPK } \\
\text { Phonska }\end{array}$ & 25 & 400,92 & 25 & 393,39 \\
\hline NPK Mutiara & 12 & 244,14 & 0 & 0 \\
\hline DAP & 9 & 150,04 & 0 & 0 \\
\hline Petroganik & 5 & $1.531,23$ & 15 & $1.508,41$ \\
\hline Kandang & 11 & $5.546,79$ & 0 & 0 \\
\hline
\end{tabular}

Sumber : Analisis Data Primer

Penggunaan pupuk merupakan usaha petani untuk meningkatkan produktivitas lahan, yaitu dengan cara menambah unsur hara yang diperlukan tanaman. Pemupukan sangat penting untuk meningkatkan produksi tanaman, yaitu dengan menambah ketersediaan unsur hara dalam tanah. Dengan demikian diharapkan kebutuhan tanaman akan unsur hara akan dapat terpenuhi secara optimal.

Tabel diatas menunjukkan bahwa petani bawang merah di Kabupaten Nganjuk lebih intensif dalam perlakuan pemupukan pada tanaman bawang merah, terutama pada pemberian pupuk tunggal yang mengandung unsur hara esensial yang dibutuhkan oleh tanaman seperti nitrogen $(\mathrm{N})$, fosfor $(\mathrm{P})$, dan kalium (K). Sementara petani di Kabupaten Bantul lebih intensif dalam pemberian pupuk majemuk yang mengandung dua atau lebih unsur hara bagi tanaman, diantara adalah pupuk NPK Phonska, NPK Mutiara, dan DAP. Selain itu, separuh petani bawang merah di Kabupaten Bantul dan Kabupaten Nganjuk sama-sama memberikan pupuk organik, baik berupa pupuk 
kandang maupun petroganik, pada lahan bawang merah mereka.

Pestisida adalah bahan yang digunakan untuk mengendalikan organisme pengganggu tanaman. Jenis-jenis pestisida yang digunakan oleh petani bawang merah antara lain herbisida, fungisida, dan insektisida. Rata-rata penggunaan pestisida untuk usahatani bawang merah dapat dilihat pada Tabel 3 .

Tabel 3. Rerata Penggunaan Pestisida untuk Usahatani Bawang Merah

\begin{tabular}{lrrrr}
\hline \multirow{2}{*}{ Jenis Pestisida } & \multicolumn{2}{c}{ Kab. Bantul } & \multicolumn{2}{c}{$\begin{array}{c}\text { Kab. } \\
\text { Nganjuk }\end{array}$} \\
\cline { 2 - 6 } & $\mathrm{N}$ & Rerata & $\mathrm{N}$ & Rerata \\
\hline Herbisida (ml/ha) & 3 & 1.140 & 2 & 4.165 \\
$\begin{array}{l}\text { Fungisida Padat } \\
\text { (gr/ha) }\end{array}$ & 2 & 5.962 & 2 & 7.873 \\
$\begin{array}{l}\text { Fungisida Cair } \\
\text { (ml/ha) }\end{array}$ & 2 & 1.123 & 6 & 1.362 \\
$\begin{array}{l}\text { Insektisida Padat } \\
\text { (gr/ha) }\end{array}$ & 4 & 857 & 8 & 10.185 \\
$\begin{array}{l}\text { Insektisida Cair } \\
\text { (ml/ha) }\end{array}$ & 2 & 1.511 & 2 & 2.361 \\
\hline
\end{tabular}

Sumber : Analisis Data Primer

Secara umum usahatani bawang merah adalah jenis usahatani yang membutuhkan banyak asupan pupuk dan pestisida. Pemberian pupuk dimaksudkan untuk menambah jumlah kandungan hara yang ada di dalam tanah, sementara pestisida ditujukan untuk mengendalikan organisme pengganggu tanaman, seperti hama, patogen penyebab penyakit tanaman, dan gulma. Tabel diatas menunjukkan bahwa petani di dua lokasi penelitian sama-sama menggunakan berbagai jenis pestisida.Alokasi pestisida petani bawang merah di Kabupaten Nganjuk sedikit lebih banyak dari petani bawang merah di Kabupaten Bantul.

Tenaga kerja merupakan salah satu faktor produksi yang utama.Sebab dalam mengelola usahataninya, petani tidak hanya menyumbangkan tenaganya tetapi juga kemampuan dan keahlian yang dimilikinya. Rerata penggunaan tenaga kerja untuk usahatani bawang merah dapat dilihat pada Tabel 4.
Tabel 4. Rerata Curahan Tenaga Kerja untuk Usahatani Bawang Merah

\begin{tabular}{|c|c|c|c|c|}
\hline \multirow{2}{*}{$\begin{array}{c}\text { Curahan } \\
\text { Tenaga } \\
\text { Kerja } \\
\text { (HKO/ha) }\end{array}$} & \multicolumn{2}{|c|}{ Kab. Bantul } & \multicolumn{2}{|c|}{ Kab. Nganjuk } \\
\hline & $\begin{array}{l}\text { Laki- } \\
\text { Laki }\end{array}$ & Wanita & $\begin{array}{l}\text { Laki- } \\
\text { Laki }\end{array}$ & Wanita \\
\hline Persiapan & & & & \\
\hline $\begin{array}{l}\text { Benih dan } \\
\text { Lahan }\end{array}$ & 58,01 & 14,38 & 59,42 & 8,64 \\
\hline $\begin{array}{l}\text { Tanam dan } \\
\text { Pmeliharaan }\end{array}$ & 447,67 & 6,90 & 307,79 & 29,24 \\
\hline Panen & 47,89 & 1,35 & 35,71 & 11,01 \\
\hline Total & 553,56 & 22,64 & 402,92 & 48,89 \\
\hline
\end{tabular}

Sumber : Analisis Data Primer

Usahatani bawang merah merupakan tipe usahatani yang membutuhkan banyak curahan tenaga kerja petani.Secara umum, curahan tenaga kerja tersebut dapat dibedakan dalam tiga jenis pekerjaan, yaitu 1) persiapan benih dan lahan, 2) tanam dan pemeliharaan, serta 3) panen.Jenis pekerjaan yang pertama meliputi pembelahan benih, pembuatan selokan, pelembutan tanah, pembuatan garis tanam, pemberian herbisida pra-tanam, dan pemberian pupuk dasar.Jenis pekerjaan yang kedua mencakup penanaman, pemupukan, penyemprotan pestisida, penyiraman, dan penyiangan.Sementara jenis pekerjaan yang ketiga meliputi panen dan pengangkutan hasil panen.

Tabel di atas menunjukkan bahwa penggunaan tenaga kerja petani di Kabupaten Bantul lebih intensif dibandingkan dengan petani di Kabupaten Nganjuk.Hal ini terlihat jelas terutama untuk jenis pekerjaan yang kedua, yaitu tanam dan pemeliharaan. Keadaan ini dapat dimengerti mengingat kondisi tanah di Kabupaten Nganjuk yang lebih subur, karena baru saja ditanami tanaman kedelai, sehingga menjadikan tanaman bawang merah tumbuh lebih sehat sehingga tidak perlu penanganan berlebih. Sementara itu, tanaman bawang merah di Kabupaten Bantul memerlukan perhatian dan penanganan lebih seperti pemupukan, penyemprotan, dan penyiraman yang lebih intensif.Akibatnya, curahan tenaga kerja yang dikeluarkan oleh petani menjadi lebih banyak. 


\section{Panen dan Produksi Bawang Merah}

Tinggi rendahnya produksi dan produktivitas bawang merah sangat dipengaruhi oleh modal yang tersedia dan teknik budidaya yang dilakukan oleh petani. Produksi dan produktivitas selanjutnya dapat digunakan untuk mengetahui apakah suatu usahatani telah dikelola dengan baik atau tidak.Rerata produksi dan produktivitas bawang merah petani dapat dilihat pada Tabel 5.Berdasarkan tabel tersebut dapat diketahui bahwa rerata produksi bawang merah petani di Kabupaten Bantul adalah sebesar 3.026,67 $\mathrm{kg}$ per usahatani atau setara dengan 12,24 ton per hektar. Sementara itu, rerata produksi bawang merah petani di
Kabupaten Nganjuk lebih tinggi lagi, yaitu sebesar $5.236,83 \mathrm{~kg}$ per usahatani atau setara dengan 20,57 ton per hektar. Produktivitas yang sangat tinggi yang dapat dicapai oleh petani di Kabupaten Nganjuk disebabkan oleh beberapa faktor, namun dua faktor yang paling dominan adalah 1) pemilihan varietas bawang merah yang ditanam di Kabupaten Nganjuk, yaitu varietas thailand yang memang memiliki potensi daya hasil tinggi, dan 2) pola tanam yang dapat menyehatkan tanah yaitu dengan menanam tanaman leguminosa yang secara alamiah dapat meningkatkan kandungan unsur $\mathrm{N}$ di dalam tanah sehingga tanaman bawang merah dapat tumbuh secara optimal.

Tabel 5. Rerata Penguasaan Lahan, Jumlah Benih, dan Produktivitas Bawang Merah

\begin{tabular}{lrr}
\hline Uraian & Kab. Bantul & Kab. Nganjuk \\
\hline Luas Lahan (ha) & 0,25 & 0,25 \\
Jumlah Benih (kg/ha) & 878,48 & 980,09 \\
Produksi (kg) & $3.026,67$ & $5.236,83$ \\
Produktivitas (kg/ha) & $12.243,69$ & $20.570,58$ \\
Produktivitas (ton/ha) & 12,24 & 20,57 \\
\hline
\end{tabular}

Sumber : Analisis Data Primer

Tabel 6. Nilai Produksi dan Sturktur Biaya Usahatani Bawang Merah

\begin{tabular}{|c|c|c|c|c|}
\hline \multirow{2}{*}{ Uraian } & \multicolumn{2}{|c|}{ Kab. Bantul } & \multicolumn{2}{|c|}{ Kab. Nganjuk } \\
\hline & Jumlah & $\%$ & Jumlah & $\%$ \\
\hline \multicolumn{5}{|l|}{ Penerimaan } \\
\hline Produksi (kg/ha) & 12.244 & & 20.571 & \\
\hline Harga (Rp) & 5.492 & & 4.308 & \\
\hline $\begin{array}{l}\text { Nilai Produksi }(\mathrm{Rp} / \mathrm{ha}) \\
\text { Biaya Variabel (Variable } \\
\text { Cost) }\end{array}$ & 67.132 .814 & & 88.744 .586 & \\
\hline Benih (Rp/ha) & 12.907 .927 & 27,92 & 15.359 .705 & 28,74 \\
\hline Pupuk (Rp/ha) & 4.079 .884 & 8,83 & 3.350 .668 & 6,27 \\
\hline Pestisida (Rp/ha) & 2.080 .691 & 4,50 & 2.347 .363 & 4,39 \\
\hline Tenaga Kerja (Rp/ha) & 21.699 .674 & 46,94 & 19.852 .803 & 37,14 \\
\hline \multicolumn{5}{|l|}{ Biaya Tetap (Fixed Cost) } \\
\hline Sewa Lahan (Rp/ha/musim) & 5.111 .508 & 11,06 & $12,315,608$ & 23,04 \\
\hline Penyusutan & 349.419 & 0,76 & 223,898 & 0,42 \\
\hline Total Biaya & 4.229 .103 & 100 & $53,450,046$ & 100 \\
\hline
\end{tabular}

Sumber : Analisis Data Primer 


\section{Nilai Produksi dan Struktur Biaya Usahatani Bawang Merah}

Salah satu indikator penting dalam penilaian ekonomi usahatani adalah dengan melihat nilai produksi yang diperoleh petani. Nilai produksi ini setelah dikurangi dengan biaya-biaya yang telah dikeluarkan akan didapatkan nilai pendapatan usahatani. Semakin tinggi pendapatan yang diterima oleh petani, maka usahataninya dapat dikatakan lebih berhasil secara ekonomi. Pendapatan inilah yang kemudian akan digunakan oleh petani untuk memenuhi kebutuhan hidupnya.

Tabel 6 menunjukkan bahwa nilai produksi petani bawang merah di Kabupaten Nganjuk lebih besar daripada petani bawang merah di Kabupaten Bantul. Nilai produksi sendiri didapatkan dengan mengalikan jumlah produksi dengan rerata harga yang dihadapi oleh petani. Nilai produksi bawang merah di Kabupaten Nganjuk cukup tinggi dikarenakan produktivitas bawang merahnya yang cukup tinggi pula.Walaupun harga jual bawang merah di Kabupaten Bantul lebih tinggi dari harga jual bawang merah di Kabupaten Nganjuk, tetap saja tidak mampu melewati nilai produksi bawang merah di Kabupaten Nganjuk.

Dilihat dari struktur biaya usahatani, tenaga kerja menjadi pos biaya yang paling tinggi karena mencakup 46,94\% dan 37,14\% dari total biaya yang harus dikeluarkan oleh petani di masing-masing kabupaten. Biaya benih menjadi pos biaya terbesar kedua setelah tenaga kerja. Sementara itu, biaya pupuk dan pestisida hanya mencakup sekitar $10-14 \%$ dari total biaya usahatani bawang merah.

\section{Profitabilitas Usahatani Bawang Merah.}

Profitabilitas usahatani menunjukkan kemampuan dari usahatani untuk menghasilkan keuntungan (profit). Profitabilitas ini berkaitan erat dengan beberapa faktor antara lain aplikasi teknologi, luas penguasaan lahan, harga input, dan harga output. Jika kenaikan harga output yang diterima petani tidak sebanding dengan kenaikan harga faktor produksi (input) yang harus dibayar oleh petani disertai dengan semakin lambatnya peningkatan produktivitas maka akan berakibat pada rendahnya efisiensi dan pendapatan petani. Dalam penelitian ini, profitabilitas usahatani dianalisis dengan menghitung Gross Margin (GM), Net Farm Income (NFI), Return on Invested Capital (ROIC), Operating Ratio (OR), dan Gross Ratio (GR) sebagaimana ditampilkan pada Tabel 7. petani bawang merah di Kabupaten Bantul memperoleh pendapatan kotor (gross farm income) sebesar Rp 67.132.814,00. Angka ini kemudian dikurangi biaya variabel sebesar Rp 40.768.176,00 sehingga didapatkan gross margin sebesar Rp 26.364.638,00. Nilai gross margin ini merupakan ukuran profitabilitas yang biasa digunakan untuk usahatani tani skala kecil. Sementara itu, petani bawang merah di Kabupaten Nganjuk memperoleh gross margin sebesar $\mathrm{Rp}$ 47.834.046,00.

Tabel 7. Profitabilitas Usahatani Bawang Merah

\begin{tabular}{lrrr}
\hline \multicolumn{1}{c}{ Uraian } & Formulasi & Kab. Bantul & Kab. Nganjuk \\
\hline Gross Farm Income (Rp/ha) & & 67.132 .814 & 88.744 .586 \\
Biaya Variabel (Variable Cost) (Rp/ha) & & 40.768 .176 & 40.910 .540 \\
Biaya Tetap (Fixed Cost) (Rp/ha) & & 5.460 .927 & 12.539 .506 \\
Total Biaya (Total Cost) (Rp/ha) & & 46.229 .103 & 53.450 .046 \\
Gross Margin (Rp/ha) & GFI - TVC & 26.364 .638 & 47.834 .046 \\
Net Farm Income (Rp/ha) & GM - TFC & 20.903 .711 & 35.294 .540 \\
Return on Invested Capital & GM / TVC & 0,65 & 1,17 \\
Operating Ratio & TVC / GFI & 0,61 & 0,46 \\
Gross Ratio & TC / GFI & 0,69 & 0,60 \\
\hline Sumber : Analisis Data Primer & & &
\end{tabular}

Sumber : Analisis Data Primer 
Hampir dua kali lipat dari gross margin petani bawang merah di Kabupaten Bantul.Semakin rendah rasio berarti semakin tinggi profitabilitas usahatani. Sedangkan gross ratio adalah rasio profitabilitas yang digunakan untuk mengukur keberhasilan usahatani dalam menghasilkan keuntungan secara keseluruhan.

Apabila nilai gross margindikurangi dengan biaya tetap maka akan menghasilkan net farm income (pendapatan bersih usahatani). Net farm income merupakan pendapatan bersih atau keuntungan dari usahatani yang dijalankan.Net farm income juga menunjukkan kemampuan usahatani dalam menghasilkan laba (keuntungan).Net farm income usahatani bawang merah di Kabupaten Bantul dan Kabupaten Nganjuk masing-masing adalah sebesar Rp 20.903.711,00 dan Rp 35.294.540,00.

Tingkat pengembalian atas modal yang telah diinvestasikan oleh petani juga penting untuk dilihat dengan tujuan untuk melihat kemampuan usahatani dalam mengembalikan modalnya. Ukuran tingkat pengembalian atas modal ini disebut Return on Invested Capital(ROIC).ROIC dihitung dengan cara membagi gross margin dengan biaya variabel total. ROIC usahatani bawang merah di Kabupaten Nganjuk didapatkan sebesar 1,17. Nilai ini lebih besar dari ROIC usahatani bawang merah di Kabupaten Bantul sebesar 0,65 .

Operating ratio adalah rasio profitabilitas yang terkait langsung (directly related) dengan tingkat penggunaan input variabel, seperti benih, pupuk, pestisida, dan tenaga kerja.

Operating ratio dan gross ratio usahatani bawang merah di dua lokasi penelitian adalah kurang dari satu yang artinya adalah usahatani bawang merah mampu menghasilkan keuntungan.

Tabel 8. Estimasi Fungsi Produksi Frontier Stokastik Tipe Cobb-Douglas Usahatani Bawang Merah di Kabupaten Bantul

\begin{tabular}{|c|c|c|c|c|}
\hline \multicolumn{2}{|l|}{ Variabel } & \multicolumn{2}{|c|}{ Koefisien } & \multirow{2}{*}{$\frac{T \text {-ratio }}{0,43289}$} \\
\hline Konstanta & $\beta_{0}$ & 0,37744 & ns & \\
\hline Luas Lahan & $\beta_{1}$ & 0,66579 & $* * *$ & 10.12172 \\
\hline Benih & $\beta_{2}$ & $-0,17112$ & ns & -0.93594 \\
\hline Pupuk Urea & $\beta_{3}$ & 0,00665 & ns & 0.72494 \\
\hline Pupuk ZA & $\beta_{4}$ & $-0,00079$ & ns & $-0,07019$ \\
\hline Pupuk SP-36 & $\beta_{5}$ & 0,01862 & $* *$ & 2,35378 \\
\hline Pupuk KCl & $\beta_{6}$ & 0,00259 & $\mathrm{~ns}$ & 0,23901 \\
\hline Pupuk NPK-Phonska & $\beta_{7}$ & 0,02641 & *** & 3,05581 \\
\hline Petroganik & $\beta_{8}$ & 0,03732 & $* * *$ & 2,78314 \\
\hline Herbisida & $\beta_{9}$ & 0,04565 & ns & 0,49650 \\
\hline Fungisida & $\beta_{10}$ & 0,05082 & $* *$ & 2,48934 \\
\hline Insektisida & $\beta_{11}$ & 0,11763 & ns & 1,45325 \\
\hline Tenaga Kerja & $\beta_{12}$ & 0,51298 & $* *$ & 2,74632 \\
\hline Sigma-squared & & 0,09427 & $* *$ & 2,0787 \\
\hline Gamma & & 0,99997 & $* * *$ & $4.911,5$ \\
\hline
\end{tabular}

\footnotetext{
Sumber : Analisis Data Primer

Keterangan :

$* * * \quad$ : signifikan pada $\alpha=1 \%$

** $\quad$ : signifikan pada $\alpha=5 \%$

* $\quad$ : signifikan pada $\alpha=10 \%$

ns : non-signifikan
} 


\section{Efisiensi Teknis Usahatani Bawang Merah di Kabupaten Bantul}

Berikut ini adalah hasil estimasi fungsi produksi stokastik frontier dengan menggunakan pendekatan Maximum Likelihood Estimation (MLE), sebagaimana ditampilkan pada Tabel 8.

Tabel tersebut menunjukkan bahwa faktor-faktor produksi seperti luas lahan, pupuk SP-36, pupuk NPK-Phonska, pupuk petroganik, fungisida, dan tenaga kerja berpengaruh nyata terhadap produksi bawang merah.Keenam faktor produksi tersebut memberikan pengaruh positif terhadap produksi bawang merah. Hal ini dapat dilihat dari koefisien yang bertanda positif sehingga dapat diartikan apabila faktor produksi luas lahan, pupuk SP-36, pupuk NPKPhonska, pupuk petroganik, fungisida, dan tenaga kerja ditambah maka produksi bawang merah akan dapat ditingkatkan.

Hasil estimasi diatas juga menunjukkan nilai sigma-squared sebesar 0,09427 dan signifikan pada $\alpha$ sebesar 5\% sehingga dapat dimaknai bahwa jumlah produksi bawang merah yang dihasilkan pada usahatani di Kabupeten Bantul mempunyai variasi yang nyata. Selain itu, nilai gamma didapatkan sebesar 0,99997 dan signifikan pada $\alpha$ sebesar $1 \%$ menunjukkan bahwa $99,9 \%$ tingkat variasi produksi bawang merah di Kabupaten Bantul disebabkan karena adanya in-efisiensi dalam proses produksi.

Secara umum, karakteristik model produksi frontier untuk menduga efisiensi teknis adalah adanya pemisahan dampak dari goncangan peubah eksogen terhadap keluaran melalui kontribusi ragam yang menggambarkan efisiensi teknis (Giannakas et al., 2003 dalam Sukiyono, 2005). Dengan kata lain, penggunaan metode ini dimungkinkan untuk menduga ketidakefisienan suatu proses produksi tanpa mengabaikan error term dari modelnya. Selain itu, pendugaan efisiensi menggunakan fungsi produksi frontier memungkinkan untuk dapat diketahui tingkat efisiensi yang dicapai oleh tiap individu unitunit usahatani (Coelli et al., 1998), sebagaimana ditampilkan pada Tabel 9 .
Tabel 9. Sebaran Efisiensi Teknis Petani Bawang Merah di Kabupaten Bantul

\begin{tabular}{ccr}
\hline Tingkat Efisiensi & Jumlah Petani & Persentase \\
\hline$<0,5$ & 4 & 13,33 \\
$0,51-0,60$ & 2 & 6,67 \\
$0,61-0,70$ & 2 & 6,67 \\
$0,71-0,80$ & 4 & 13,33 \\
$0,81-0,90$ & 6 & 20,00 \\
$0,91-1,00$ & 12 & 40,00 \\
Jumlah & 30 & \\
Rerata & 0,802 & \\
Nilai Minimum & 0,289 & \\
Nilai Maksimum & 0,997 & \\
\hline
\end{tabular}

Sumber : Analisis Data Primer

Tingkat efisiensi yang dicapai oleh petani bawang merah di Kabupaten Bantul berkisar antara 0,289 hingga 0,997, dengan persentase terbanyak pada kelompok tingkat efisiensi $0,91-1,00$ sebesar $40 \%$. Sedangkan jumlah petani pada tingkat efisiensi $0,81-0,90$ merupakan jumlah terbanyak kedua dengan persentase sebesar $20 \%$. Tingkat efisiensi ratarata adalah sebesar 0,802 yang merupakan tingkat efisiensi yang cukup tinggi dan masih ada ruang bagi petani untuk meningkatkannya lagi.

Tabel 10. Estimasi Faktor-Faktor yang Mempengaruhi In-Efisiensi Teknis Usahatani Bawang Merah di Kabupaten Bantul

\begin{tabular}{|c|c|c|c|c|}
\hline \multicolumn{2}{|l|}{ Variabel } & \multicolumn{2}{|c|}{ Koefisien } & T-ratio \\
\hline Konstanta & $\delta_{0}$ & 0,01913 & $\mathrm{~ns}$ & 0,01971 \\
\hline Umur & $\delta_{1}$ & 0,34254 & $\mathrm{~ns}$ & 0,47087 \\
\hline Pendidikan & $\delta_{2}$ & $-0,85495$ & * & $-1,35717$ \\
\hline Pengalaman & $\delta_{3}$ & 0,17452 & ns & 0,26972 \\
\hline
\end{tabular}

Sumber : Analisis Data Primer

Keterangan :

* $\quad$ : signifikan pada $\alpha=15 \%$

ns : non-signifikan

Faktor-faktor yang diduga mempengaruhi in-efisiensi teknis usahatani bawang merah di Kabupaten Bantul adalah umur, pendidikan, dan pengalaman petani.Hasil estimasi pada Tabel 10 menunjukkan bahwa hanya pendidikan yang berpengaruh nyata terhadap 
in-efisiensi usahatani bawang merah pada tingkat $\alpha$ sebesar $15 \%$.Tingkat pendidikan memiliki koefisien bertanda negatif yang dapat dimaknai bahwa semakin tinggi tingkat pendidikan petani, maka semakin kecil petani tersebut melakukan ketidakefisienan dalam menjalankan usahatani bawang merah. Atau dengan kata lain, semakin tinggi tingkat pendidikan petani maka petani tersebut akansemakin efisien dalam menjalankan usahataninya.

\section{Efisiensi Teknis Usahatani Bawang Merah di Kabupaten Nganjuk}

Tabel 11 adalah hasil estimasi fungsi produksi stokastik frontier dengan menggunakan pendekatan Maximum Likelihood Estimation (MLE).

Tabel 11 menunjukkan bahwa faktorfaktor produksi yang berpengaruh nyata terhadap produksi bawang merah di Kabupaten Nganjuk adalah luas lahan, fungisida, dan insektisida. Masing-masing variabel tersebut secara berurutan berpengaruh nyata pada tingkat $\alpha$ sebesar $1 \%, 5 \%$, dan 5\%. Dari tanda pada koefisien dapat dilihat bahwa ketiga faktor produksi tersebut memberikan pengaruh positif sehingga dapat diartikan apabila faktor produksi luas lahan, fungisida, dan insektisida ditambah maka produksi bawang merah akan dapat ditingkatkan. Sementara variabel-variabel lain yang juga dimasukkan ke dalam model, seperti benih, pupuk urea, pupuk ZA, pupuk SP-36, pupuk KCl, pupuk NPK-Phonska, pupuk petroganik, herbisida, dan tenaga kerja tidak berpengaruh nyata terhadap produksi bawang merah.

Hasil estimasi diatas juga menunjukkan nilai sigma-squared sebesar 0,00590 dan signifikan pada $\alpha$ sebesar $1 \%$ sehingga dapat dimaknai bahwa jumlah produksi bawang merah yang dihasilkan pada usahatani di Kabupeten Nganjuk mempunyai variasi yang nyata.

Tabel 11. Estimasi Fungsi Produksi Frontier Stokastik Tipe Cobb-Douglas Usahatani Bawang Merah di Kabupaten Nganjuk

\begin{tabular}{|c|c|c|c|c|}
\hline \multicolumn{2}{|l|}{ Variabel } & \multicolumn{2}{|c|}{ Koefisien } & \multirow{2}{*}{$\frac{\text { T-ratio }}{1,24161}$} \\
\hline Konstanta & $\beta_{0}$ & 0,57044 & ns & \\
\hline Luas Lahan & $\beta_{1}$ & 0,97546 & $* * *$ & 26,75222 \\
\hline Benih & $\beta_{2}$ & 0,03621 & $\mathrm{~ns}$ & 0,64285 \\
\hline Pupuk Urea & $\beta_{3}$ & 0,00883 & $\mathrm{~ns}$ & 0,86316 \\
\hline Pupuk ZA & $\beta_{4}$ & 0,00172 & ns & 0,74264 \\
\hline Pupuk SP-36 & $\beta_{5}$ & $-0,00040$ & $\mathrm{~ns}$ & $-0,18802$ \\
\hline Pupuk KCl & $\beta_{6}$ & 0,04212 & ns & 1,30219 \\
\hline Pupuk NPK-Phonska & $\beta_{7}$ & $-0,00207$ & ns & $-0,89334$ \\
\hline Petroganik & $\beta_{8}$ & 0,00016 & ns & 0,09547 \\
\hline Herbisida & $\beta_{9}$ & 0,00354 & $\mathrm{~ns}$ & 1,18218 \\
\hline Fungisida & $\beta_{10}$ & 0,00840 & $* *$ & 2,12723 \\
\hline Insektisida & $\beta_{11}$ & 0,00502 & $* *$ & 2,44239 \\
\hline Tenaga Kerja & $\beta_{12}$ & $-0,03746$ & ns & $-0,26439$ \\
\hline Sigma-squared & & 0,00590 & $* * *$ & 3,2760 \\
\hline Gamma & & 0,99999 & $* * *$ & 11,61 \\
\hline
\end{tabular}

Sumber : Analisis Data Primer

Keterangan :

*** : signifikan pada $\alpha=1 \%$

** : signifikan pada $\alpha=5 \%$

* : signifikan pada $\alpha=10 \%$

ns : non-signifikan 
Selain itu, nilai gamma didapatkan sebesar 0,99999 dan signifikan pada $\alpha$ sebesar $1 \%$ menunjukkan bahwa $99,9 \%$ tingkat variasi produksi bawang merah di Kabupaten Nganjuk disebabkan karena adanya in-efisiensi dalam proses produksi.

Tabel 12.Sebaran Efisiensi Teknis Petani Bawang Merah di Kabupaten Nganjuk

\begin{tabular}{ccr}
\hline Tingkat Efisiensi & Jumlah Petani & Persentase \\
\hline$<0,5$ & 0 & 0,00 \\
$0,51-0,60$ & 0 & 0,00 \\
$0,61-0,70$ & 0 & 0,00 \\
$0,71-0,80$ & 3 & 10,00 \\
$0,81-0,90$ & 7 & 23,33 \\
$0,91-1,00$ & 20 & 66,67 \\
Jumlah & 30 & \\
Rerata & 0,929 & \\
Nilai Minimum & 0,750 & \\
Nilai Maksimum & 0,999 & \\
\hline
\end{tabular}

Sumber : Analisis Data Primer

Tabel 13. Estimasi Faktor-Faktor yang Mempengaruhi In-Efisiensi Teknis Usahatani Bawang Merah di Kabupaten Nganjuk

\begin{tabular}{llrll}
\hline \multicolumn{1}{c}{ Variabel } & \multicolumn{2}{c}{ Koefisien } & T-ratio \\
\hline Konstanta & $\delta_{0}$ & 1,42197 & $* * * *$ & 2,88003 \\
Umur & $\delta_{1}$ & 0,25452 & $*$ & \\
& & - & & $-1,56697$ \\
Pendidikan & $\delta_{2}$ & 0,09224 & ns & $-1,05620$ \\
Pengalaman & $\delta_{3}$ & 0,10763 & ns & \\
\hline
\end{tabular}

Sumber : Analisis Data Primer

Keterangan :

$* * * * \quad$ : signifikan pada $\alpha=1 \%$

*** : signifikan pada $\alpha=5 \%$

** : signifikan pada $\alpha=10 \%$

* $\quad$ : signifikan pada $\alpha=15 \%$

ns : non-signifikan

Tingkat efisiensi yang dicapai oleh petani bawang merah di Kabupaten Nganjuk, sebagaimana ditampilkan pada Tabel 12 berkisar antara 0,750 hingga 0,999 . Persentase terbanyak berada pada kelompok tingkat efisiensi $0,91-1,00$ sebesar $66,67 \%$. Sedangkan jumlah petani pada tingkat efisiensi
0,81-0,90 merupakan jumlah terbanyak kedua dengan persentase sebesar $23,33 \%$ dan kemudian sisanya berada pada tingkat efisiensi 0,71-0,80. Tingkat efisiensi rata-rata adalah sebesar 0,929.Hal ini merupakan tingkat efisiensi yang tinggi, meskipun tetap masih ada ruang bagi petani untuk meningkatkannya lagi.

Tabel 13 menunjukkan hasil estimasi faktor-faktor yang mempengaruhi in-efisiensi usahatani bawang merah di Kabupaten Nganjuk.Faktor-faktor yang diduga mempengaruhi terjadinya in-efisiensi teknis adalah umur, pendidikan, dan pengalaman petani.

Hasil estimasi menunjukkan bahwa umur berpengaruh nyata terhadap in-efisiensi usahatani bawang merah pada tingkat $\alpha$ sebesar 15\%.Umur petani memiliki koefisien bertanda negatif yang dapat dimaknai bahwa semakin tua umur petani, maka semakin kecil petani tersebut melakukan ketidakefisienan dalam menjalankan usahatani bawang merah. Atau dengan kata lain, semakin tua umur petani maka petani tersebut akan semakin efisien dalam menjalankan usahataninya. Hal ini dapat terjadi karena semakin matang umur seseorang akan semakin adaptif terhadap inovasi teknologi dalam budidaya bawag merah.

\section{KESIMPULAN DAN SARAN}

Hasil penelitian menunjukkan bahwa (1) kegiatan usahatani bawang merah di Kabupaten Bantul dan Kabupaten Nganjuk adalah usahatani yang menguntungkan dengan keuntungan bersih (net farm income) masingmasing sebesar Rp 20.903.711,00/ha dan Rp 35.294.540,00/ha, (2) rata-rata tingkat efisiensi teknis petani bawang merah di Kabupaten Bantul dan Kabupaten Nganjuk adalah masingmasing 0,802 dan 0,929, (3) tingkat efisiensi teknis usahatani bawang merah di Kabupaten Bantul dipengaruhi oleh tingkat pendidikan petani, dan tingkat efisiensi teknis usahatani bawang merah di Kabupaten Nganjuk dipengaruhi oleh umur petani.

Peningkatan produksi dan keuntungan usahatani bawang merah di Kabupaten Bantul dan Kabupaten Nganjuk masih dapat dilakukan dengan menambah luas lahan garapan bila masih memungkinkan dan juga dengan mengalokasikan faktor-faktor produksi secara optimal.Tingkat efisiensi teknis usahatani 
bawang merah masih dapat ditingkatkan dengan meningkatkan kualitas sumber daya manusia (SDM) petani melalui kegiatan penyuluhan dan pelatihan oleh dinas terkait.

\section{DAFTAR PUSTAKA}

Adiyoga, W. 1999. Beberaapa Alternatif Pendekatan untuk Mengukur Efisiensi atau In-Efisiensi dalam Usahatani. Jurnal Informatika Pertanian. Vol 8.

Balitbang Pertanian. 2005. Prospek dan Arah Pengembangan Agribisnis Bawang Merah. Departemen Pertanian. Jakarta

Bank Indonesia. 2013. Pola Pembiayaan Usaha Kecil Menengah Usaha Budidaya Bawang Merah. Departemen
Pengembangan Akses Keuangan dan UMKM. Jakarta

Bappenas. 2014. Studi Pendahuluan Rencana Pembangunan Jangka Menengah Nasional (RPJMN) Bidang Pangan dan Pertanian 2015-2019. Direktorat Pangan dan Pertanian. Jakarta

Coelli, 1996. A Guide to Frontier Version 4.1 :Program for Stochastic Frontier Production and Cost Function Estimation. CEPA Working Paper 07/96. University of New England. Australia

Mubyarto. 1982. Pengantar Ekonomi Pertanian. LP3ES. Jakarta. 